\title{
Perilaku Gizi, Status Gizi, dan Morbiditas Penyakit Infeksi pada Petani dan Buruh Tani Perempuan di Pemalang
}

\author{
Nutritional Behavior, Nutritional Status, and Infectious \\ Diseases Morbidity of Female Farmers and Farmworkers \\ in Pemalang
}

\author{
Desiani Rizki Purwaningtyas $^{(1)}$, Sri Anna Marliyati( ${ }^{(2)}$ \\ (1) Program Studi Gizi Fakultas Ilmu-Ilmu Kesehatan Universitas Muhammadiyah Prof. DR. HAMKA \\ (UHAMKA) Jakarta \\ ${ }^{(2)}$ Departemen Gizi Masyarakat IPB Bogor
}

\begin{abstract}
Korespondensi Penulis: Desiani Rizki Purwaningtyas, Program Studi Gizi Fakultas Ilmu-Ilmu Kesehatan Universitas Muhammadiyah Prof. DR. HAMKA (UHAMKA) Jakarta,

E-mail: desianirizki@gmail.com
\end{abstract}

\begin{abstract}
ABSTRAK
Kualitas Sumber Daya Manusia (SDM) pertanian merupakan faktor penting dalam keberhasilan pembangunan Indonesia sebagai negara agraris. Pembangunan kualitas SDM pertanian erat kaitannya dengan status gizi dan morbiditas penyakit infeksi yang juga berhubungan dengan perilaku gizi. Oleh karena itu, penelitian ini bertujuan untuk mengkaji perilaku gizi, status gizi, dan morbiditas penyakit infeksi pada petani dan buruh tani perempuan di Kecamatan Taman Kabupaten Pemalang, Jawa Tengah. Penelitian ini merupakan studi kuantitatif dengan desain cross-sectional. Subyek pada penelitian ini adalah 97 petani dan buruh tani pada perempuan di Kecamatan Taman Kabupaten Pemalang, Jawa Tengah dengan teknik sampling cluster random sampling. Pengumpulan data melalui pengukuran antropometri dan wawancara dengan menggunakan kuesioner. Uji statistik yang digunakan adalah Chi-Square. Hasil penelitian ini menunjukkan bahwa sebagian besar responden memiliki pengetahuan gizi yang kurang, sikap gizi positif, praktek gizi dan keamanan pangan sedang, status gizi normal berdasarkan Indeks Massa Tubuh (IMT) dan Lingkar Lengan Atas (LLA), dan morbiditas penyakit infeksi yang rendah. Uji Chi-Square menunjukkan pengetahuan gizi berhubungan signifikan dengan status gizi berdasarkan IMT. Morbiditas penyakit infeksi tidak berhubungan signifikan dengan status gizi berdasarkan IMT, tetapi berhubungan signifikan dengan status gizi berdasarkan LLA.
\end{abstract}

Kata Kunci: Perilaku gizi, status gizi, penyakit infeksi, petani

\begin{abstract}
Quality of farmers as human resources is an important matter in success of Indonesia national development with considering Indonesia is an agriculture country. Human resources development has close relationship with nutritional status and morbidity of infectious disease which are also connected with nutritional behavior. So, this study aims was to analyze the nutritional behavior, nutritional status, and infectious diseases morbidity in female farmers and farmworkers at Taman, Pemalang Regency, Central Java Province. The research was a quantitative study with desaign cross-sectional. Subjects of this study were 97 farmers and farmworkers in Taman, Pemalang-Central Java with sampling technique used cluster random sampling. In the data collecting, researchers conducted antropometric measurement and interviews with questionnaire as measuring tool. The statistic test used Chi-Square. The result of this study showed that most of subjects had less nutrition knowledge, positive nutrition attitude, medium nutrition practice, normal nutritional status based on BMI and up arm circumference, and low morbidity of infectious diseases. ChiSquare test showed that there was significant correlation between nutritional knowledge and nutritional status based on BMI. Infectious diseases morbidity had no significant correlation with nutritional status based on BMI but it had significant correlation with nutritional status based on up arm circumference.
\end{abstract}

Keyword: Nutritional, behavior, nutritional status, infectious disease, farmers 


\section{PENDAHULUAN}

Keberhasilan pembangunan suatu bangsa ditentukan oleh ketersediaan Sumber Daya Manusia (SDM) yang berkualitas yang dicerminkan dari Indeks Pembangunan Manusia (Human Development Index-HDI). Pada 2015 posisi HDI Indonesia berada pada ranking 113 dari 188 negara (UNDP, 2016). Indonesia merupakan negara agraris yang pembangunannya banyak bertumpu pada sektor pertanian dan tidak terlepas dari kualitas SDM pelaku sektor pertanian tersebut khususnya petani dan buruh tani.

Masalah gizi yang tidak terlepas dari pangan dapat menyebabkan rendahnya kualitas SDM. Pangan merupakan salah satu kebutuhan dasar manusia yang pemenuhannya menjadi hak asasi setiap rakyat Indonesia. Oleh karena itu, pangan yang dikonsumsi manusia harus mengandung gizi yang tinggi dan aman (Hariyadi, 2002). Status gizi yang baik akan menurunkan prevalensi masalah gizi. Ada beberapa hal yang mempengaruhi status gizi. Perilaku gizi yang buruk akan berpengaruh pada status gizi yang cenderung rendah. Terdapat korelasi negatif antara morbiditas penyakit infeksi dengan status gizi. Penyakit infeksi merupakan permasalahan kesehatan di Indonesia yang sebagian besar warganya adalah masyarakat ekonomi menengah ke bawah. Penyakit infeksi dapat timbul karena beberapa hal yang tidak lepas dari makanan. Perilaku keamanan pangan yang buruk juga akan dapat menimbulkan penyakit infeksi (Christi, 2010).

Berdasarkan Riskesdas, Pemalang mempunyai prevalensi yang tinggi pada beberapa penyakit infeksi (Kemenkes, 2013). Oleh karena itu, penelitian tentang hubungan antara perilaku gizi dan keamanan pangan dengan status gizi dan morbiditas penyakit infeksi pada petani dan buruh tani perempuan di Kecamatan Taman Kabupaten Pemalang, Jawa Tengah penting dilakukan. Petani dan buruh tani perempuan diambil sebagai contoh karena selain profesinya tersebut, sebagian besar dari mereka adalah ibu rumah tangga yang langsung menangani atau mengolah makanan yang akan dikonsumsi oleh keluarganya. Sementara itu, Kabupaten Pemalang, Jawa Tengah diambil sebagai lokasi penelitian karena wilayah tersebut merupakan daerah pertanian padi yang potensial dengan jumlah petani dan buruh tani perempuan yang tinggi. Berdasarkan data di Dinas Pertanian Kabupaten Pemalang, jumlah petani dan buruh tani perempuan sebanyak 14.498 orang dari total petani 24.164 orang. Akan tetapi, kualitas sumber daya manusia petani perempuan di daerah tersebut masih kurang memadai.

\section{SUBYEK DAN METODE}

Penelitian ini merupakan studi kuantitatif dengan desain cross-sectional. Populasi penelitian adalah petani dan buruh tani berjenis kelamin perempuan di Kabupaten Pemalang, Jawa Tengah. Penarikan sampel dilakukan dengan menggunakan metode cluster random sampling. Kriteria inklusi yang ditetapkan adalah petani atau buruh tani perempuan, berada dalam usia subur (belum mengalami menopause), dan bersedia menjadi responden dalam penelitian ini. Sampel dalam penelitian ini berjumlah 97 orang yang telah memenuhi jumlah sampel minimal. Petani merupakan seseorang yang memiliki pekerjaan di sektor pertanian dan memiliki lahan sendiri sedangkan buruh tani tidak memiliki lahan sendiri melainkan bekerja di lahan orang lain.

Data yang dikumpulkan berupa data primer yang meliputi karakteristik umum responden, perilaku gizi, status gizi berdasarkan Indeks Massa Tubuh (IMT) dan Lingkar Lengan Atas (LLA), serta morbiditas penyakit infeksi. Data karakteristik umum responden meliputi usia, tingkat pendidikan, dan tingkat pendapatan. Usia dikategorikan menjadi dewasa dan separuh baya. Kelompok usia dewasa berada pada rentang usia 19-35 tahun sedangkan separuh baya berusia 3650 tahun (Sumarwan, 2003). Tingkat pendidikan sampel dikategorikan menjadi tidak lulus sekolah menengah dan lulus sekolah menengah. Tingat pendapatan sampel dikategorikan menjadi miskin dan tidak miskin mengacu pada angka kemiskinan untuk Kabupaten Pemalang yaitu Rp 198.814,00 per kapita per bulan. Responden yang memiliki tingkat pendapatan di bawah angka kemiskinan tergolong miskin (BPS, 2011). Perilaku gizi meliputi pengetahuan, sikap, dan praktek gizi. Pengetahuan gizi responden dikategorikan menjadi baik dan kurang. Seseorang dikategorikan memiliki pengetahuan gizi baik jika skornya $>80$ (Khomsan, 2000). 
Sikap gizi dikategorikan menjadi positif dan negatif dilihat berdasarkan nilai rata-rata. Praktek gizi dikategorikan menjadi baik dan kurang dilihat berdasarkan nilai rata-rata. Morbiditas penyakit infeksi didefinisikan sebagai kejadian sakit infeksi yang ditemukan pada responden selama tiga bulan terakhir dilihat dari pernah atau tidaknya menderita jenis penyakit infeksi yang diteliti (ISPA, diare, disentri, tifus, dan hepatitis A), frekuensi sakit, dan lama sakit. Morbiditas penyakit infeksi dikategorikan menjadi rendah dan tinggi. Status gizi yang diukur mencakup status gizi berdasarkan Indeks Massa Tubuh (IMT) dan Lingkar Lengan Atas (LLA). Pengukuran LLA dimaksudkan untuk mengetahui kondisi Kurang Energi Kronis (KEK). Pengumpulan data karakteristik umum, perilaku gizi, dan morbiditas penyakit infeksi dilakukan dengan teknik wawancara dengan bantuan kuesioner. Data status gizi diperoleh dari pengukuran antropometri berupa $\mathrm{BB}, \mathrm{TB}$, dan lingkar lengan atas. Uji statistik yang digunakan adalah Chi-Square untuk menganalisis hubungan antara perilaku gizi dengan status gizi serta hubungan antara status gizi dengan morbiditas penyakit infeksi pada petani dan buruh tani perempuan.

\section{HASIL}

Distribusi sebagian besar responden, baik petani maupun buruh tani berada pada usia separuh baya. Berdasarkan tingkat pendidikan, sebagian besar petani perempuan yang menjadi sampel $(58,9 \%)$ telah menyelesaikan sekolah menengah sedangkan sebagian besar buruh tani $(68,3 \%)$ tidak lulus sekolah menengah. Berdasarkan tingkat pendapatan, sebagian besar buruh tani $(61 \%)$ tergolong miskin sedangkan sebagian besar petani $(94,6 \%)$ tergolong tidak miskin. Berdasarkan uji Chi-Square terdapat perbedaan yang signifikan pada variabel tingkat pendidikan dan tingkat pendapatan antara petani dan buruh tani perempuan. Namun, tidak terdapat perbedaan yang signifikan pada variabel usia antara petani dan buruh tani perempuan (tabel 1).

Distribusi sebagian besar responden baik petani maupun buruh tani memiliki pengetahuan dan praktek gizi yang kurang serta sikap gizi yang positif. Berdasarkan uji Chi-Square terdapat perbedaan yang signifikan pada variabel praktek gizi antara petani dan buruh tani perempuan. Namun, tidak terdapat perbedaan yang signifikan pada variabel pengetahuan dan sikap gizi antara petani dan buruh tani perempuan (tabel 2).

Tabel 1. Distribusi Responden Berdasarkan Karakteristik Umum

\begin{tabular}{llccccc}
\hline \multirow{2}{*}{ Variabel } & \multicolumn{1}{c}{ Kategori } & \multicolumn{2}{c}{ Buruh Tani } & \multicolumn{2}{c}{ Petani } & \multirow{2}{*}{ P Value } \\
& & $\mathbf{n}$ & $\mathbf{\%}$ & $\mathbf{n}$ & $\mathbf{\%}$ & \\
\hline \multirow{2}{*}{ Usia } & Dewasa & 16 & 39,0 & 23 & 41,1 & \multirow{2}{*}{0,995} \\
& Separuh baya & 25 & 61,0 & 33 & 58,9 & \\
\multirow{2}{*}{ Tingkat Pendidikan } & Tidak lulus sekolah menengah & 28 & 68,3 & 23 & 41,1 & \multirow{2}{*}{0,001} \\
& Lulus sekolah menengah & 13 & 31,7 & 33 & 58,9 & \\
\multirow{2}{*}{ Tingkat Pendapatan } & Miskin & 25 & 61,0 & 3 & 5,4 & \multirow{2}{*}{0,000} \\
& Tidak miskin & 16 & 39,0 & 53 & 94,6 & \\
\hline
\end{tabular}

Tabel 2. Distribusi Responden Berdasarkan Perilaku Gizi

\begin{tabular}{|c|c|c|c|c|c|c|}
\hline \multirow{2}{*}{ Variabel } & \multirow{2}{*}{ Kategori } & \multicolumn{2}{|c|}{ Buruh Tani } & \multicolumn{2}{|c|}{ Petani } & \multirow{2}{*}{ PValue } \\
\hline & & $\mathbf{n}$ & $\%$ & $\mathbf{n}$ & $\%$ & \\
\hline \multirow[t]{2}{*}{ Pengetahuan Gizi } & Kurang & 39 & 95,1 & 56 & 100,0 & \multirow{2}{*}{0,098} \\
\hline & Baik & 2 & 4,9 & 0 & 0,0 & \\
\hline \multirow[t]{2}{*}{ Sikap Gizi } & Negatif & 20 & 48,8 & 27 & 48,2 & \multirow{2}{*}{0,781} \\
\hline & Positif & 21 & 51,2 & 29 & 51,8 & \\
\hline \multirow[t]{2}{*}{ Praktek Gizi } & Kurang & 39 & 95,1 & 39 & 69,6 & \multirow{2}{*}{0,000} \\
\hline & Baik & 2 & 4,9 & 17 & 30,4 & \\
\hline
\end{tabular}


Distribusi sebagian besar responden memiliki status gizi normal baik berdasarkan IMT maupun LLA. Proporsi kurang energi kronis lebih banyak terdapat pada buruh tani. Berdasarkan uji Chi-Square terdapat perbedaan yang signifikan pada variabel morbiditas penyakit infeksi antara petani dan buruh tani perempuan. Namun, tidak terdapat perbedaan yang signifikan pada variabel status gizi baik berdasarkan IMT maupun LLA antara petani dan buruh tani perempuan (tabel 3). Hubungan antara perilaku gizi dengan status gizi responden berdasarkan IMT menunjukkan sebagian besar responden yang berpengetahuan gizi kurang memiliki status gizi yang normal berdasarkan IMT. Semua responden yang berpengetahuan gizi baik memiliki status gizi yang normal. Semua responden yang gemuk memiliki pengetahuan gizi yang kurang. Hasil

Tabel 3. Distribusi Responden Berdasarkan Status Gizi dan Morbiditas Penyakit Infeksi

\begin{tabular}{llccccc}
\hline \multirow{2}{*}{ Variabel } & \multirow{2}{*}{ Kategori } & \multicolumn{2}{c}{ Buruh Tani } & \multicolumn{2}{c}{ Petani } & \multirow{2}{*}{ P Value } \\
& & $\mathbf{n}$ & $\mathbf{\%}$ & $\mathbf{n}$ & $\mathbf{\%}$ & \\
\hline Status Gizi IMT & Gemuk & 15 & 36,6 & 21 & 37,5 & \multirow{2}{*}{0,189} \\
\multirow{2}{*}{ Status Gizi LLA } & Normal & 26 & 63,4 & 35 & 62,5 & \\
\multirow{3}{*}{ Morbiditas Penyakit Infeksi } & KEK & 7 & 17,1 & 3 & 5,4 & \multirow{2}{*}{0,062} \\
& Normal & 34 & 82,9 & 53 & 94,6 & \\
& Tinggi & 4 & 9,8 & 1 & 1,8 & \multirow{2}{*}{0,015} \\
& Rendah & 37 & 90,2 & 55 & 98,2 & \\
\hline
\end{tabular}

Tabel 4. Hubungan antara Perilaku Gizi dengan Status Gizi berdasarkan IMT

\begin{tabular}{llccccc}
\hline \multirow{2}{*}{ Variabel } & \multicolumn{1}{c}{ Kategori } & \multicolumn{2}{c}{ Gemuk } & \multicolumn{2}{c}{ Normal } & P Value \\
& & n & \% & n & \% & \\
\hline Pengetahuan Gizi & Kurang & 36 & 37,9 & 59 & 62,1 & \multirow{2}{*}{0,027} \\
& Baik & 0 & 0,0 & 2 & 100,0 & \\
Sikap Gizi & Negatif & 19 & 40,4 & 28 & 59,6 & \multirow{2}{*}{0,556} \\
& Positif & 17 & 34,0 & 33 & 66,0 & \\
Praktek Gizi & Kurang & 29 & 37,2 & 49 & 62,8 & 0,400 \\
& Baik & 7 & 36,8 & 12 & 63,2 & \\
\hline
\end{tabular}

Tabel 5. Hubungan antara Perilaku Gizi dengan Status Gizi berdasarkan LLA

\begin{tabular}{llccccc}
\hline \multirow{2}{*}{ Variabel } & \multicolumn{1}{c}{ Kategori } & \multicolumn{2}{c}{ KEK } & \multicolumn{2}{c}{ Normal } & \multirow{2}{*}{ P Value } \\
& & n & \% & n & \% & \\
\hline Pengetahuan Gizi & Kurang & 10 & 10,5 & 85 & 89,5 & \multirow{2}{*}{0,166} \\
& Baik & 0 & 0,0 & 2 & 100,0 & \\
\multirow{2}{*}{ Sikap Gizi } & Negatif & 4 & 8,5 & 43 & 91,5 & \multirow{2}{*}{0,560} \\
& Positif & 6 & 12,0 & 44 & 88,0 & \\
& Kurang & 8 & 10,3 & 70 & 89,7 & 0,610 \\
\hline
\end{tabular}

Tabel 6. Hubungan antara Status Gizi dengan Morbiditas Penyakit Infeksi

\begin{tabular}{rlrcccc}
\hline \multirow{2}{*}{ Variabel } & \multirow{2}{*}{ Kategori } & \multicolumn{2}{c}{ Tinggi } & \multicolumn{2}{c}{ Rendah } & P Value \\
& & n & \% & n & \% & \\
\hline \multirow{2}{*}{ Status Gizi IMT } & Gemuk & 3 & 8,3 & 33 & 91,7 & \multirow{2}{*}{0,465} \\
& Normal & 2 & 3,3 & 59 & 96,7 & \\
\multirow{2}{*}{ Status Gizi LLA } & KEK & 1 & 10,0 & 9 & 90,0 & \multirow{2}{*}{0,031} \\
& Normal & 4 & 4,6 & 83 & 95,4 & \\
\hline
\end{tabular}


uji Chi-Square menunjukkan adanya hubungan yang signifikan antara pengetahuan gizi dengan status gizi berdasarkan IMT. Sebagian besar responden dengan sikap gizi negatif dan positif sama-sama memiliki status gizi yang normal berdasarkan IMT. Berdasarkan praktek gizi responden, sebagian besar responden baik yang memiliki praktek gizi yang baik maupun kurang juga memiliki status gizi normal. Tidak terdapat hubungan yang signifikan antara sikap dan praktek gizi dengan status gizi berdasarkan IMT (tabel 4).

Hubungan antara perilaku gizi dengan status gizi responden berdasarkan LLA menunjukkan bahwa sebagian besar responden berpengetahuan gizi kurang dan semua responden berpengetahuan gizi baik memiliki status gizi normal berdasarkan LLA. Semua responden yang mengalami kurang energi kronis merupakan responden berpengetahuan gizi kurang. Berdasarkan sikap gizinya, sebagian besar responden bersikap gizi negatif dan positif memiliki status gizi normal berdasarkan LLA. Berdasarkan praktek gizinya, sebagian besar responden dengan prakte gizi kurang dan baik juga sama-sama tidak mengalami kurang energi kronis. Hasil uji Chi-Square menunjukkan tidak terdapat hubungan yang signifikan antara pengetahuan, sikap, dan praktek gizi dengan status gizi berdasarkan LLA (tabel 5).

Hubungan antara status gizi dengan morbiditas infeksi menunjukkan bahwa sebagian besar responden dengan status gizi normal dan gemuk memiliki morbiditas penyakit infeksi yang rendah. Morbiditas penyakit infeksi yang tinggi cenderung lebih banyak terdapat pada responden yang gemuk meskipun tidak signifikan secara statistik. Jika ditinjau dari status gizi berdasarkan LLA, sebagian besar responden yang kurang energi kronis dan normal juga memiliki morbiditas penyakit infeksi yang rendah. Akan tetapi, proporsi morbiditas penyakit infeksi yang tinggi lebih banyak terdapat pada responden yang mengalami kurang energi kronis. Hasil uji ChiSquare menunjukkan terdapat hubungan yang signifikan antara status gizi berdasarkan LLA dengan morbiditas penyakit infeksi. Responden yang mengalami KEK cenderung memiliki morbiditas penyakit infeksi yang lebih tinggi (tabel 6).

\section{DISKUSI}

Petani perempuan bekerja di bidang pertanian dan memiliki lahan sendiri sedangkan buruh tani tidak memiliki lahan sendiri melainkan bekerja untuk petani. Tingkat pendidikan dan pendapatan antara petani dan buruh tani perempuan memiliki perbedaan signifikan. Banyak perempuan yang menjadi buruh tani terutama pada keluarga pra sejahtera. Faktor utama yang mendorong perempuan mau bekerja sebagai buruh adalah faktor ekonomi. Selain itu ada beberapa faktor yang menyebabkan mereka menjadi buruh di antaranya adalah pendidikan dan keterampilan. Sebagian besar buruh memiliki status pendidikan dan ekonomi yang lebih rendah dibandingkan dengan pemilik lahan (Nurianti, 2017).

Perbedaan tingkat pendidikan dan tingkat pendapatan antara petani dan buruh tani perempuan dapat berdampak pada perilaku gizi yang mencakup domain pengetahuan, sikap, dan praktek gizi. Meskipun pengetahuan dan sikap gizi tidak memiliki perbedaan signifikan, tetapi praktek gizi antara petani dan buruh tani perempuan memiliki perbedaan signifikan. Praktek gizi petani signifikan lebih baik dibandingkan buruh tani. Praktek gizi yang diteliti meliputi penerapan gizi seimbang dan praktek hidup bersih dan sehat. Tingkat pendapatan yang rendah pada buruh tani membuat mereka kurang akses atau kurangnya daya beli untuk membeli makanan-makanan sesuai dengan pedoman gizi seimbang. Sebagian besar buruh tani menghidangkan makanan untuk keluarganya hanya sebatas pada sumber karbohidrat, sumber protein nabati, dan sayuran. Proporsi sumber karbohidrat dalam sekali makan sangat dominan dengan satu atau dua potong tempe atau tahu dan sedikit sayuran. Buah-buahan dan sumber protein hewani jarang muncul di dalam menu makanan mereka karena dianggap komoditas yang mahal. Hasil ini sejalan dengan penelitian lain yang menyebutkan bahwa ada hubungan yang signifikan antara pendapatan keluarga dengan konsumsi buah dan sayur (Suryani et al., 2015). Keluarga dengan status ekonomi yang tinggi lebih mampu menyediakan beranekaragam makanan seperti daging, ikan, dan buah-buahan dibandingkan keluarga dengan status ekonomi rendah (Rachman et al., 2017). Kuantitas dan 
kualitas makanan yang dikonsumsi seseorang tidak lepas kaitannya dengan pendapatan. Peluang untuk memilih pangan yang baik akan meningkat dengan semakin besanya pendapatan. Pendapatan yang meningkat akan berdampak pada perubahan-perubahan dalam susunan menu (Suhardjo, 2006).

Idealnya, perilaku gizi akan berpengaruh terhadap status gizi dan morbiditas penyakit infeksi. Sebagian besar petani dan buruh tani memiliki status gizi normal berdasarkan IMT dan LLA. Tidak ada perbedaan signifikan antara petani dan buruh tani. Hal tersebut dapat terjadi karena kedua indikator status gizi tersebut lebih dipengaruhi oleh kecukupan energi. Meskipun makanan yang dikonsumsi tidak beragam dan tidak sesuai dengan pedoman gizi seimbang, tetapi konsumsi energinya mencukupi maka dapat mencapai status gizi normal berdasarkan IMT dan LLA. Jika dilihat dari pengamatan peneliti terhadap responden dan mengacu pada jawaban responden di kuesioner praktek gizi, sebagian besar responden tidak menunjukkan kecenderungan kurang energi pada pola makannya karena dalam satu porsi makanan mereka, makanan sumber karbohidrat sangat dominan dan rata-rata lebih dari setengah piring. Sebagian besar responden tidak mengalami kesulitan akses terhadap pangan pokok sumber karbohidrat yaitu nasi karena sebagian besar responden yang diteliti adalah petani dan buruh tani padi. Setiap panen mereka menyisihkan beras untuk konsumsi pribadi sebelum dijual. Uji statistik menunjukkan adanya hubungan yang signifikan antara pengetahuan gizi dengan status gizi berdasarkan IMT. Responden yang pengetahuan gizinya kurang secara signifikan lebih banyak yang mengalami kegemukan dibanding dengan responden dengan pengetahuan gizi baik. Pengetahuan gizi yang kurang menyebabkan pola makannya semakin menjauh dari gizi seimbang dengan proporsi karbohidrat yang berlebihan sehingga meningkatkan risiko obesitas (Loliana \& Nadhiroh, 2015).

Morbiditas penyakit infeksi pada buruh tani lebih tinggi dibandingkan pada petani. Hal tersebut diduga karena pola makan pada buruh tani kurang beragam sehingga kekurangan zat gizi tertentu seperti protein serta vitamin dan mineral terutama yang berperan sebagai antioksidan yang dapat menurunan daya tahan tubuh sehingga rentan terkena penyakit infeksi. Penyakit infeksi tersebut juga berhubungan dengan status gizi. Kerangka konsep UNICEF menjelaskan bahwa status gizi saling berhubungan dengan penyakit infeksi. Seseorang yang mengalami status gizi kurang akan rentan mengalami penyakit infeksi. Begitu juga sebaliknya, seseorang yang mengalami penyakit infeksi akan mengalami kesulitan mengasup makanan dan ada penurunan metabolisme zat-zat gizi di dalam tubuh sehingga dapat menurunkan status gizi (UNICEF, 1997). Pada penelitian ini ditemukan hubungan yang signifikan antara status gizi berdasarkan LLA dengan morbiditas penyakit infeksi. Responden yang mengalami KEK memiliki morbiditas penyakit infeksi yang lebih tinggi. Hasil penelitian ini sejalan dengan penelitian lain yang mengungkapkan bahwa penyakit infeksi merupakan salah satu faktor risiko KEK pada wanita (Mahirawati, 2014).

\section{KESIMPULAN}

Sebagian besar responden memiliki pengetahuan gizi yang kurang, sikap gizi positif, dan praktek gizi yang kurang tepat. Terdapat perbedaan signifikan antara praktek gizi petani dan buruh tani. Sebagian besar responden memiliki status gizi yang normal berdasarkan IMT dan LLA, serta morbiditas penyakit infeksi yang rendah. Namun, terdapat perbedaan signifikan pada morbiditas penyakit infeksi. Morbiditas pada buruh tani lebih tinggi dibandingkan petani. Terdapat hubungan yang signifikan antara pengetahuan gizi dengan status gizi berdasarkan IMT. Status gizi berdasarkan LLA berhubungan signifikan dengan morbiditas penyakit infeksi.

\section{DAFTAR PUSTAKA}

Badan Pusat Statistik (BPS). (2011). Jumlah dan Persentase Penduduk Miskin, Garis Kemiskinan, Indeks Kedalaman Kemiskinan, dan Indeks Keparahan Kemiskinan Menurut Provinsi. http:// www.bps.go.id.

Christi, K. (2010). Food Habits and Nutritional Status of Fiji Rugby Players. World Academy of Science, Enginering, and Technology, 68.

Hariyadi, P. (2002). Kajian Sistim Koordinasi Pengelolaan Mutu dan Keamanan Pangan. Bogor: Jurusan Gizi Masyarakat dan Sumber daya Keluarga Fakultas Pertanian IPB. 
Kementerian Kesehatan (Kemenkes) RI. (2013). Laporan Hasil Riset Kesehatan Provinsi Jawa Tengah. Jakarta: Kemenkes RI.

Khomsan, A. (2000). Teknik Pengukuran Pengetahuan Gizi. Bogor: Jurusan Gizi Masyarakat Sumberdaya Keluarga Fakultas Pertanian IPB.

Loliana, N., \& Nadhiroh, S. R. (2015). Asupan dan Kecukupan Gizi antara Remaja Obesitas dengan Non Obesitas. Media Gizi Indonesia, 10(2), 141145.

Mahirawati, V. K. (2014). Faktor-Faktor yang Berhubungan dengan Kekurangan Energi Kronis pada Ibu Hamil di Kecamatan Kamoning dan Tambelangan, Kabupaten Sampang, Jawa Timur. Buletin Penelitian Sistem Kesehatan, 17(2), 193202.

Nurianti, L. (2017). Pembagian Peran Buruh Tani Perempuan. Jurnal Fisip Universitas Airlangga.

Rachman, B. N., Mustka, I. G., Kusumawati, I. G. A. W. (2017). Faktor yang Berhubungan dengan Perilaku Konsumsi Buah dan Sayur Siswa SMP Di Denpasar. Jurnal Gizi Indonesia, 6(1).

Suhardjo. (1989). Sosio Budaya Pangan. Bogor: Pusat Antar Universitas Pangan dan Gizi IPB

Sumarwan U. (2003). Perilaku Konsumen Teori dan Penerapannya dalam Pemasaran. Bogor: Ghalia Indonesia.

Suryani, N., Anwar, R., Wardani, H. K. (2015). Hubungan Status Ekonomi dengan Konsumsi Buah, Sayur dan Pengetahuan terhadap Status Gizi pada Siswa SMP di Perkotaan dan Pedesaan di Kotamadya Banjar Baru Tahun 2014. Jurnal Kesehatan Indonesia, 5(3), 6-15.

UNICEF. (1997). Conceptual Framework Determinants of Malnutrition. New York: UNICEF.

United Development Programme (UNDP). (2016). Human Development Report 2016: Human Development for Everyone. New York: UNDP. 